\title{
IMPROVING TEACHERS' PROFESSIONALISM THROUGH MATERIALS DEVELOPMENT, INFORMATION TECHNOLOGY AND CLASSROOM ACTION RESEARCH
}

\author{
Emalia Iragiliati Sukarni \\ State University of Malang, Indonesia \\ Dwi Winarni \\ Yuliana Tri Nirmayanti \\ National Plus Catholic High School St. Albertus Malang, Indonesia
}

\begin{abstract}
One of the ways to promote the International standard schools' teacher professionalism was to carry out weekly workshops on material development based on curriculum pathways of the National Plus High Schools using the Information Technology (IT) facilities. This research developed teacher-made materials for the $\mathrm{X}$ grade. The materials were graded: narrative, recount, news item, descriptive, ranging from 250 to 500 words. The materials were then tried out in a Classroom Action Research (CAR) at eight classes of X grades. Based on previous research, teachers' preferences are made in line with the students' choice of issues to be discussed. It aimed at knowing the feasibility of the materials, the students' preference of exercises and students' level of competencies of each class related to the understanding of the units. Results of the questionnaires showed that most of the materials were understood and liked by the students. Thus, professionalism was seen during the process of the CAR.
\end{abstract}

Key words: teachers' professionalism, materials development, information teachnology, Classroom Action Research

Establishing international-standard schools has created controversies among academics in Indonesia these days. Those who support this new approach of schooling, backed by the Indonesian government, have taken few 
steps ahead in implementing the idea; on the other side, those who are against have been questioning the urgency and necessity of such kind of implementation. A big step taken by the Indonesian Ministry of National Education was formulating the plan to build National Plus schools throughout Indonesia within a five-year initiative program. Those National Plus schools should develop National Plus curriculum, which incorporates the national curriculum as well as additional content, in the form of English for Specific Purposes.

The National Plus Schools, which in 2007 totaled 198 throughout Indonesia, have to shift their way of presenting school subjects - the subjects have to be presented in Bahasa Indonesia as well as in English. This kind of condition increases the demand of independent bilingual teachers, who master the subject and at the same time have sound knowledge and adequate level of proficiency in English. This condition, however, creates problems because non-English teachers have relatively weak skills and knowledge of the English language.At this stage, teachers who are required to use English as the medium of instructions are teachers of Chemistry, Biology, Mathematics, Physics and English (Ministry of National Education, 2007).

There was additional information from the Teacher Institute of the Sampoerna Foundation (Sampoerna Foundation Teacher Institute, 2007) on characteristics and indicators of National Plus Schools. According to the Institute, National Plus schools should encourage professional development for teachers. This is a commitment to plan and implement ongoing staff professional development. In doing it, the Institute proposed the following indicators: 1) teachers should be committed to participate in shared professional development activities where teachers from various schools can exchange and develop educational practices; 2) teachers should participate each year in a workshop or seminar related to international standards and developments; 3) structures should exist within the school for ongoing internal staff training and development; 4) regular meetings are held in the school for on-going planning and development; 5) regular appraisal of staff performances should be given by designated line manager; 6) there should be a commitment to provide staff with ongoing language training support in their non-native language.

St. Albertus Private Catholic High School Malang, East Java, as one of the 198 selected high schools has to provide teachers of the five subjects with consultants for each field of study from the local universities (Ministry of National Education, 2007). Guided by the hired consultants, the non English teachers were expected to be able to produce students' worksheets during the first year. 
Furthermore, they were also expected to be able to teach in their field of study using English as the medium of instruction during the third year.

The followings are problems faced by the English language teachers, including the ones in St Albertus. These problems need to be addressed in establishing international standard schools: 1) teachers lack of updated information on language teaching, assessments, and its implementation in real life situation classroom; 2) teachers are not used to make their own materials for the classroom; 3) in most schools, teachers are not facilitated with Information Technology (IT) facilities; 4) in the case when there are IT facilities at schools, some of the teachers do not know how to operate the IT facilities in order to obtain teaching materials for classroom; 5) teachers' exposure to international seminars such as presenting papers is limited; 6) teachers have limited exposure in writing articles for journals, proceedings, books; 7) teachers lack skill to write weekly report on their activities in the weekly workshops; and 8) teachers are hardly able to validate the teaching materials.

\section{METHOD}

The objective of this study is to improve the professional skills of teachers through a change of mind sets. A change of mind set is the a change in the mind from a basic mind set of a teacher to a mind set of a professional teacher. The change of mind sets can be seen in the following activities: 1) training the teachers to make their own materials for the classroom using examples from THE SPOTLIGHT (Sukarni et. al., 2008), English for Specific Purposes (Hutchinson \& Waters, 2006; Sukarni, 2007) books and papers (Sukarni, 2005; Iragiliati, 1993) and curriculum book and paper (Richards, 2001; Sukarni, 2007) and other authentic materials using IT (www.americanfolklore.net iwww.lestariheritage.net; www.culture.melayuonline.com; etc.);2) facilitating the teachers with exposure to international seminars such as paper presenter that would in turn have a positive impact on the teachers with a change of mind sets during their professional development; 3 ) facilitating the teachers with exposure in writing articles for seminar proceedings, journals, books; 4) training the teachers on how to validate the teaching materials produced as in the "try out' of the materials. In this study, we are pinpointing on how to train the teachers in validating the teaching materials produced as in the 'try out' of the materials. 
In regard of the objectives stated above, Classroom Action Research (CAR) was chosen (Burns, 2003; Wallace, 1998; van Lier, 1988; Freeman, 1998). The choice was based on the assumptions that the teachers would be involved from the start and as the results from the approach in the cycles of the CAR would not only be of benefit to the teachers but could also be applied to other contexts as well.

The study involved six English teachers of Senior High School of the National Plus St. Albert Catholic School, Malang, East Java, Indonesia. They are also members of the Teacher Support Group (MGMP). The weekly workshops for the teachers at the school were carried out for five hours each week. At the first semester of the first year, the teachers had made the National Plus High School syllabus with pathways adhered to the needs of the students and in the second semester, the teachers carried out the Classroom Action Research of the materials of the Xth grade. The activities of the CAR consisted of a) write English textbooks for the $\mathrm{X}$ grade and try out the materials. It was also expected that the teachers would present a paper on the progress of the first cycle of CAR at an international seminar. The aim was to open up their horizons to academic exposure to English in real life situation.

Data in this research were teachers' classroom activities in the proposed activities. It was also stated that at the end of each semester, there would be an evaluation of the activities. The data were collected through open-ended questionnaires (McDonough \& McDonough, 1997: 176) on the materials tried out. Results of the data analysis of the materials in one semester were further explored using the questionnaire to the students during classroom interactions.

In this study, the technique used for collecting the data is using a questionnaire for the application of authentic materials for the Xth grade. Based on previous research, teachers' preferences are in line with the students' choice of issues to be discussed. The materials consist of six units on: procedure related to banking and entertainment (Unit 1), narrative text: Fables and Myths (Unit 2), Recount of famous sportmen (Unit 3), descriptive text of Indonesia and its traditional houses (Unit 4), news items text related to environmental issues (Unit 5) and narrative text about ghost stories and mysteries (Unit 6). The data collected from the results of the questionnaire of the materials is based on the needs analysis of the students. Burns (2003:131) states that the questionnaire would provide opportunities for unforeseen responses that are richer and more detailed. 
Data analysis in action research involves moving away from the "action" components of the cycle, where the main focus is on planning and acting, to the 'research' aspect, where the focus changes to more systematic observing and reflecting. It involves describing or the 'what' of the research and explaining or the 'why' of the research (Burns, 2003: 153). In this study, the analysis was on the result of the questionnaire for the students on the materials for the $X$ th grade that were tried out.

In this study, the time triangulation chosen was longitudinal or over a period of time. The choice was to get a sense of what factors are involved in change process (Burns, 2003: 164) during the try out of the materials developed.

\section{FINDINGS}

In the proposed action on collaborative action research in practice, Burns (2003:214) suggests that it offers opportunities for informal individual thinking to be transported into a more systematic and collective problem-solving.

\section{Materials Developed for the Xth grade and Its Try Out}

The units in this book are based on the pathways of the syllabus with the number of words ranging from 250 to 500 words (Iragiliati et.al: 2007:29). In developing materials based on the students' need, the teacher should prepare data and data sources. Data at this try out were classroom interactions between teacher and students and classroom interactions between students and students at $\mathrm{X}$ grades for several meetings. There is only one data source at the try out. The data source was X grades students in a class during try out time (see Table 1). The materials were tried out simultaneously in eight classes of $X$ grades. Each teacher had the chance to try out the unit they developed in two classes. The six units being tried out are all designed for ten meetings of 45 minutes each.

Table 1. Data and Data Sources

\begin{tabular}{lll}
\hline Data & Data Sources \\
\hline 1. & Clasroom interactions between \\
teacher and students & 1. & $\begin{array}{l}\text { X graders students in a class dur- } \\
\text { ing try out time. }\end{array}$ \\
$\begin{array}{l}\text { 2. } \begin{array}{l}\text { Clasroom interactions between } \\
\text { students and students }\end{array} \\
\text { 2. }\end{array}$ & $\begin{array}{l}\text { X graders students in a class dur- } \\
\text { ing try out time. }\end{array}$ \\
\hline
\end{tabular}


The teacher was active as the data collector or key instrument supported by another instrument such as questionnaire. In collecting the data, the teacher was involved in the process as participant observer.

Table 2. Primary Source, Techniques and Instruments

\begin{tabular}{|c|c|c|}
\hline Primary Source & Techniques & Instrumentation \\
\hline 1. Observation & Participant observation & Note taking \\
\hline 2. Questionnaire & $\begin{array}{l}\text { - Items with options } \\
\text { - Items with explantion }\end{array}$ & $\begin{array}{l}\text { - Questions for readibility } \\
\text { and like or dislike. } \\
\text { - Wording the result of the } \\
\text { questionnaire. }\end{array}$ \\
\hline
\end{tabular}

However, there were difficulties in getting data from the source ( see Table 2 above). First, the teacher had limited time in conducting the try out due to the school final test schedules. Second, the teaching schedules of teacher for XI graders could not always match with the teaching schedules of the teacher for $\mathrm{X}$ graders. The following are the report of the try out and the results of the questionnaires.

Unit 1 is a procedure text type. The sub unit of listening deals with how to send and withdraw money from the bank. While in speaking, the students are asked to rearrange a number of sentences so that they form the correct procedure, for example, how to make a cup of coffee and an omellete. Then, they practice saying or giving that procedure in pairs. Reading session covers other procedure texts of 200 and 400 words in sending money through an agent location and a procedure on how to be a good master of ceremony or MC. The writing session allows the students to make their own instructions on how to play certain games. In terms of grammar, this unit stresses the use of simple present tense, action verbs and imperative sentences since they are closely related to procedure. The students are also given a series of vocabulary exercises that include fill-in and matching. The result on the questionnaire on Unit 1/Procedure Text will be discussed in Table 3 . 
218 TEFLIN Journal, Volume 20, Number 2, August 2009

Table 3. Result on the Questionnaire on Unit 1/Procedure Text

\begin{tabular}{|c|c|c|c|c|}
\hline $\begin{array}{l}\text { Topic/ } \\
\text { Genre }\end{array}$ & Skills & $\begin{array}{c}\text { Grade/ } \\
\text { Class } \\
\end{array}$ & $\begin{array}{l}\text { Result on the } \\
\text { questionnaire }\end{array}$ & Reasons \\
\hline $\begin{array}{l}\text { Unit } 1 \\
\text { Procedure }\end{array}$ & $\begin{array}{l}\text { Listening } \\
\text { Speaking } \\
\text { Reading } \\
\text { Writing }\end{array}$ & $\begin{array}{l}\text { X-1 } \\
\text { class }\end{array}$ & $\begin{array}{l}\text { - } 90 \%=\text { under- } \\
\text { stood the in- } \\
\text { structions well } \\
80 \%=\text { liked } \\
\text { the topic on } \\
\text { banking and } \\
\text { the exercises }\end{array}$ & $\begin{array}{l}\text { - they are clear, simple } \\
\text { and short } \\
\text { - they are short, simple } \\
\text { and relatively easy to } \\
\text { do as they reflect daily } \\
\text { life experience. } \\
\text { - The exercises encour- } \\
\text { age the students to } \\
\text { work in group allowing } \\
\text { them to know and sup- } \\
\text { port each other in learn- } \\
\text { ing process. } \\
\text { - The difficulties the stu- } \\
\text { dents faced mostly oc- } \\
\text { cured as the result of } \\
\text { having limited vocabu- } \\
\text { lary, being bored and } \\
\text { lazy to keep up with } \\
\text { other students who are } \\
\text { able to learn faster. } \\
\text { - Thus, it is necessary to } \\
\text { provide games related } \\
\text { to the topic and a glos- } \\
\text { sary in addition to ask- } \\
\text { ing the students to } \\
\text { bring and use diction- } \\
\text { ary. }\end{array}$ \\
\hline
\end{tabular}

The genre used in unit 2 is narrative which specifically discussed fables and myths. The listening activities focus on how to get specific information by completing the gaps while listening to the teacher reading the listening script of selected fables and myths. The students are then expected to perform a play re- 
lated to a fable or myth as their speaking activity in which they are required to be confident and cooperative as well because this is done in a group. The sub unit of reading provides the students with a number of texts such as a myth from Trinidad and a story with a local content called Queen Aji Bidara Putih (iwww.culture.melayuonline.com) - with interesting activities in the form of matching pictures with the paragraphs, answering questions related to the texts and doing some substitution and crossword puzzle to enhance the students' understanding and vocabulary building. The writing section leads the students on how to write notes and a fable based on the morals given. The language components learnt are subject and object pronouns, the simple past tense, adverb of manner both in listening and reading. The result on the questionnaire on Unit 2/Narrative Text will be discussed in Table 4.

Table 4. Result on the Questionnaire on Unit 2/Narrative Text

\begin{tabular}{|c|c|c|c|c|}
\hline $\begin{array}{l}\text { Topic/ } \\
\text { Genre }\end{array}$ & Skills & $\begin{array}{c}\text { Grade/ } \\
\text { Class }\end{array}$ & $\begin{array}{l}\text { Result on the question- } \\
\text { naire }\end{array}$ & Reasons \\
\hline $\begin{array}{l}\text { Unit } 2 \\
\text { narrative }\end{array}$ & $\begin{array}{l}\text { Listening } \\
\text { Speaking } \\
\text { Reading } \\
\text { Writing }\end{array}$ & $\begin{array}{l}\text { - X-1 } \\
\text { class } \\
\text { The } \\
\text { ques- } \\
\text { tion- } \\
\text { aire } \\
\text { were } \\
\text { given } \\
\text { to } 49 \\
\text { stu- } \\
\text { dents. }\end{array}$ & $\begin{array}{l}\text { - } 61 \%=\text { understood the } \\
\text { material on listening } \\
\text { about finding the } \\
\text { meaning of the words } \\
\text { in the dictionary } \\
\text { - 55\% = liked the listen- } \\
\text { ing material given on } \\
\text { listening task about an- } \\
\text { swer the questions } \\
\text { - } 24 \%=\text { found and sug- } \\
\text { gested that short para- } \\
\text { graphs with simple vo- } \\
\text { cabulary are easy to } \\
\text { understand for listen- } \\
\text { ing. } \\
\text { - } 71 \%=\text { the listening } \\
\text { materials and exercises } \\
\text { in unit } 2 \text { were very }\end{array}$ & $\begin{array}{l}\text { - it is easy with clear } \\
\text { instruction. Be- } \\
\text { sides, the students } \\
\text { were allowed to use } \\
\text { the dictionary. } \\
\text { - it was fun and in- } \\
\text { teresting and also } \\
\text { they were free to } \\
\text { give their own an- } \\
\text { swers. } \\
\text { - they are easy and } \\
\text { fun to do with clear } \\
\text { and frequently used } \\
\text { instructions. } \\
\text { - it is interesting and } \\
\text { has a clear instruc- } \\
\text { tion. }\end{array}$ \\
\hline
\end{tabular}


Table 4. continued

beneficial to practise concentrating for listening which later on will improve their vocabulary and pronunciation.

- Almost half of the students (some $45 \%$ to $53 \%$ ) could understand and do the exercises on vocabulary and grammar well by stating true or false and filling the blanks

- $10 \%$ of them understood what they had to do with the exercises

- $44 \%$ of them liked the activities and thought that it would bring more knowledge for them.

- For reading, 57\% stated that they understood and liked doing the exercise in which they match pictures with the titles of the books
- The students really needed help to understand some explanation before they worked on grammatical items as only

- matching exercise is interesting and has a clear instruction. Since this kind of narrative is very familiar to learners of any ages, it is very likely that the students will easily get attracted into it for the stories, the pictures and the morals as well. Thus, the teachers are challenged to be critically able to develop the source to students' level of learning so that the material development will not turn into something too light for high school level.

Unit 3 is about recount. It discusses a biography of a famous basketball player. This is mainly because basketball is one of the favourite sports among of the teens. So, the history of basketball is given at the beginning of the unit to give the students appropriate background knowledge. As it is showed on the first page of the unit, the students start by writing words dealing with the topic 
as their listening preparation. The questions involving informative or $\mathrm{WH}$ questions are divided into two parts and are given before and after the students listen to the script. This is aimed as a means to pay attention to the listening text and to measure whether or not they understand the text. The speaking part encourages the students to talk about their own experiences during the holiday with the hope that they will be able to do it fluently as it is a real life experience they are familiar with. For those who need some help, a set of questions are given to lead them speaking. The reading section covers reading for details, for meaning, and for ideas. The text is about Dirk Werner Nowitzki, a famous German-descendant basketball player playing in NBA, the world famous basketball tournament run in USA. The students then apply their knowledge on recount by writing the biography of their father or mother based on an example given. The language components learnt for grammar provides information about the importance of the simple past tense, past continuous tense and past perfect tense with vocabulary stocks explaining word-class based on reading texts given. The result on the questionnaire on Unit 3/Recount Text will be discussed in Table 5.

Table 5. Result on the Questionnaire on Unit 3/Recount Text

\begin{tabular}{|c|c|c|c|c|}
\hline $\begin{array}{l}\text { Topic/ } \\
\text { Genre }\end{array}$ & Skills & $\begin{array}{l}\text { Grade/ } \\
\text { Class }\end{array}$ & $\begin{array}{l}\text { Result on the ques- } \\
\text { tionnaire }\end{array}$ & Reasons \\
\hline $\begin{array}{l}\text { Unit } 3 \\
\text { re- } \\
\text { count }\end{array}$ & $\begin{array}{l}\text { Listening } \\
\text { Speaking } \\
\text { Reading } \\
\text { Writing }\end{array}$ & $\begin{array}{l}\text { - X-1 } \\
\text { class } \\
\text { - The } \\
\text { data } \\
\text { were } \\
\text { taken } \\
\text { from } \\
26 \text { stu- } \\
\text { dents. }\end{array}$ & $\begin{array}{l}\text { - } 52 \%=\text { understood } \\
\text { the material given } \\
\text { on listening task on } \\
\text { the History of Bas- } \\
\text { ketball } \\
\text { - } 27 \%=\text { really under- } \\
\text { stood the listening } \\
\text { task } \\
\text { - } 43 \%=\text { liked the lis- } \\
\text { tening material } \\
\text { given for it gives } \\
\text { them media for lis- } \\
\text { tening practice. } \\
\text { - } 85 \%=\text { understood } \\
\text { the learning material }\end{array}$ & $\begin{array}{l}\text { - the listening task has } \\
\text { clear and familiar instruc- } \\
\text { tion. } \\
\text { - Having previously learnt } \\
\text { the grammatical items, } \\
\text { the students found the } \\
\text { simple past tense, past } \\
\text { continuous tense and past } \\
\text { perfect tense were quite } \\
\text { understandable and they } \\
\text { liked them along with the } \\
\text { exercises which most of } \\
\text { the students thought easy } \\
\text { to do } \\
\text { the language was simple } \\
\text { and understandable and it } \\
\text { gave them a chance to }\end{array}$ \\
\hline
\end{tabular}


Table 4. continued

- $46 \%=$ liked it.

- $80 \%=$ understood and liked the activities for speaking section share ideas with friends.

- The vocabulary stocks were believed to improve and enrich the students' word bank

- materials should be carefully designed to meet the need of the students so that teachers and students will experience a fun learning process

Unit 4 is about description of traditional house and property advertisement. This unit exposes the students to traditional house and property advertisment text consisting of 350 words. The listening section brings the students to deeper knowledge on parts of traditional houses (www. lestariheritage.net) in Indonesia which then are used for speaking session about unique houses while learning and applying some expressions such as those of asking and giving information, guessing, surprise, right and wrong. The reading texts specificaly talk about Indonesian traditional houses namely; Sakkudei house (310 words), and Traditional House of Kudus (400 words) with detailed technical vocabulary. The sub unit of writing tries to help the students write persuasive description in terms of house advertisement. The grammar in this unit provides information about how to differentiate facts from personal opinions and how to put them into use in property brochures with the words related to parts of houses through crossword puzzle. The result on the questionnaire on Unit 4/Descriptive Text will be discussed in Table 6.

Table 6. Result on the Questionnaire on Unit 4/Descriptive Text

\begin{tabular}{|c|c|c|c|c|}
\hline $\begin{array}{l}\text { Topic/ } \\
\text { Genre }\end{array}$ & Skills & $\begin{array}{c}\text { Grade/ } \\
\text { Class }\end{array}$ & $\begin{array}{l}\text { Result on the ques- } \\
\text { tionnaire }\end{array}$ & Reasons \\
\hline $\begin{array}{l}\text { Unit } 4 \\
\text { description }\end{array}$ & $\begin{array}{l}\text { Listening } \\
\text { Speaking } \\
\text { Reading } \\
\text { Writing }\end{array}$ & $\begin{array}{l}\text { X-1 } \\
\text { class }\end{array}$ & $\begin{array}{l}\text { - } 67 \%=\text { understood the } \\
\text { listening material } \\
\text { about identifying } \\
\text { parts of three }\end{array}$ & $\begin{array}{l}\text { - The task on The Long } \\
\text { House of The Dayak, } \\
\text { Rumoh Aceh, and }\end{array}$ \\
\hline
\end{tabular}


Sukarni, Winarni, \& Nirmayanti,Improving Teacher's Professionalism 223

\begin{tabular}{|c|c|c|}
\hline Table 6 continued. & & \\
\hline & $\begin{array}{l}\text { traditional houses. } \\
\text { - } 69 \%=\text { liked the lis- } \\
\text { tening material given } \\
\text { - } 7 \%=\text { the unit some- } \\
\text { what boring. } \\
\text { - } 79 \%=\text { understood } \\
\text { and were familiar } \\
\text { with the material they } \\
\text { frequently heard in } \\
\text { movies or English } \\
\text { TV programs }\end{array}$ & $\begin{array}{l}\text { Light House type and } \\
\text { the language used was } \\
\text { familiar to them in } \\
\text { addition to clear in- } \\
\text { structions for the ac- } \\
\text { tivites. } \\
\text { - The listening material } \\
\text { was fun and challeng- } \\
\text { ing with more prefer- } \\
\text { ences on having ac- } \\
\text { tivities which make } \\
\text { the materials far more } \\
\text { interesting, challeng- } \\
\text { ing and understand- } \\
\text { able. } \\
\text { - The students were also } \\
\text { challenged with the } \\
\text { pre-listening part that } \\
\text { required them to pre- } \\
\text { dict the content of the } \\
\text { text. } \\
\text { - Learning and using } \\
\text { certain expressions } \\
\text { did not seem to be a } \\
\text { problem. } \\
\text { - It can be inferred that } \\
\text { writing descriptive } \\
\text { really needs the ability } \\
\text { to explore details of } \\
\text { objects. Thus, it is im- } \\
\text { portant to give the } \\
\text { students activities to } \\
\text { encourage them to } \\
\text { build and apply ap- } \\
\text { propriate vocabulary. }\end{array}$ \\
\hline
\end{tabular}

The genre used in Unit 5 is news item. Its essence is to encourage students to access, manage and present information. This unit discussed Environmental 
Education issues. It covered the four language skills and language components on the first page. Listening for key information using the Wh-Questions is the focus of listening skill as the answers of those questions will be sources of information needed to write a news item. Speaking session will talk more in how to prepare a short talk or impromptu talk based on certain topics such as Pollution around Us, Let's Clean up Our River, Go Green! More trees! Water, Water Everywhere, Let's Save Our Coral Reefs (adapted from Sukarni, 2002) Reading skill covers reading for details, for meaning, and for ideas. The texts generally talk about environmental awareness; Looking for the Forest through the Trees (400 words), and Communities Learn How to Treat Householdwaste Waste (640 words). Both reading texts were taken from The Jakarta Post. Writing skill discusses how to write news item based on interview. Language components learnt for grammar provides information about the importance of direct and indirect speech in writing news item. It includes how to use punctuation marks in direct speech and how to change direct speech into indirect speech. Vocabulary session explains newspaper terms and newspaper in details. It also provides word-class based on reading texts given. The result on the questionnaire on Unit 5/News Item Text will be discussed in Table 7.

\section{Table 7. Result on the Questionnaire on Unit 5/News Item Text}

\begin{tabular}{|c|c|c|c|c|}
\hline $\begin{array}{l}\text { Topic/ } \\
\text { Genre }\end{array}$ & Skills & $\begin{array}{c}\text { Grade/ } \\
\text { Class }\end{array}$ & $\begin{array}{l}\text { Result on the ques- } \\
\text { tionnaire }\end{array}$ & Reasons \\
\hline $\begin{array}{l}\text { - Unit } 5 \\
\text { - news } \\
\text { item } \\
\text { - The } \\
\text { question- } \\
\text { naire for } \\
\text { unit } 5 \\
\text { covers } \\
\text { listening } \\
\text { skill and } \\
\text { grammar } \\
\text { only due } \\
\text { to the } \\
\text { limited }\end{array}$ & $\begin{array}{l}\text { Listening } \\
\text { Speaking } \\
\text { Reading } \\
\text { Writing }\end{array}$ & $\begin{array}{l}\text { - X-1 } \\
\text { class } \\
\text { - The } \\
\text { data } \\
\text { were } \\
\text { taken } \\
\text { from } \\
13 \text { stu- } \\
\text { dents. }\end{array}$ & $\begin{array}{l}\text { - } 69 \%=\text { understood } \\
\text { learning material } \\
\text { given on listening } \\
\text { task about identify- } \\
\text { ing the who, what, } \\
\text { when, where, why, } \\
\text { and how. } \\
\text { - } 69 \%=\text { liked the lis- } \\
\text { tening material given } \\
\text { because it was fun } \\
\text { and not too difficult. } \\
61.5 \%=\text { understood } \\
\text { the material in learn- } \\
\text { ing punctuation } \\
\text { marks in direct }\end{array}$ & $\begin{array}{l}\text { - The task type on } \\
\text { listening task was } \\
\text { familiar to them } \\
\text { and the instructions } \\
\text { were clear. } \\
\text { - In terms of like and } \\
\text { dislike, the listen- } \\
\text { ing material given } \\
\text { was fun and not too } \\
\text { difficult. } \\
\text { - In answering what } \\
\text { type of listening } \\
\text { materials are easily } \\
\text { understood, they } \\
\text { suggested pictures, }\end{array}$ \\
\hline
\end{tabular}


Sukarni, Winarni, \& Nirmayanti,Improving Teacher's Professionalism 225

\begin{tabular}{|c|c|c|}
\hline Table 7 continued. & & \\
\hline $\begin{array}{l}\text { time in } \\
\text { conduct- } \\
\text { ing the } \\
\text { try out at } \\
\text { the X } \\
\text { grades. } \\
\text { - The stu- } \\
\text { dents } \\
\text { were } \\
\text { asked on } \\
\text { the ques- } \\
\text { tionnaire } \\
\text { in terms } \\
\text { of readi- } \\
\text { bility and } \\
\text { like or } \\
\text { dislike. }\end{array}$ & $\begin{array}{l}\text { speech using news- } \\
\text { paper easily } \\
\text { - } 53.8 \%=\text { liked the } \\
\text { type of material } \\
\text { - } 38.5 \%=\text { too easy } \\
\text { and boring. } \\
\text { - there were many dif- } \\
\text { ferent answers in an- } \\
\text { swering what type of } \\
\text { grammar materials } \\
\text { are easily under- } \\
\text { stood: all types (15.3 } \\
\%), \text { true or false } \\
(7.7 \%), \text { showing pic- } \\
\text { tures \& examples } \\
(7.7 \%) \text {, finding simi- } \\
\text { lar grammatical pat- } \\
\text { tern on the text } \\
(15.3 \%)\end{array}$ & $\begin{array}{l}\text { examples and step } \\
\text { by step instructions. } \\
\text { - For the type of lis- } \\
\text { tening materials } \\
\text { they like, only one } \\
\text { student wrote that } \\
\text { he liked listening to } \\
\text { stories. Other stu- } \\
\text { dents didn't answer } \\
\text { the questions due to } \\
\text { their misunder- } \\
\text { standing. }\end{array}$ \\
\hline
\end{tabular}

The narrative texts in unit 6 refer to what are commonly heard as ghost stories and mysteries. The reason for bringing this kind of texts to class was a thought that any topic related to ghost has always invited discussion since it has unexplained aspects. This unit is alloted for ten meetings of 45 minutes each. Like all previous units, the students will also have to work on all four language skills and related language components listed on the first page of the unit. Listening section consists of reading texts entitled The Fifty-Cent Piece and The Telltale Seaweed which allow the students to practice their listening ability and show their understanding by completing and doing the exercises that follow. They also have to work with passsive construction and adjectives end in -ing and - ed based on the ghost story they just have heard and read. The next step is to apply the information into use in the exercises given. Another text about ghost, Piece by Piece is used as the warming up activity for speaking session that will give students a chance to talk and share ideas using common expressions of asking and giving opinions involving showing agreement and disagreement. Some interesting topics related to teenager life are given for speaking practice done in groups or pairs. The sub unit of reading is completed with 
the exercises and questions for details, meaning, and ideas. The texts entitled Milk Bottles and The Ghost Ship of Captain Sandovate were taken and adapted from American folklores [www.americanfolklore.net] ranging from 400 to 500 words. In addition to the reading exercises, the students will have to observe, learn and apply the use of adjective clause in narrative texts. There is also a Japanese story, Ubazakura, and a detective mystery case in writing section which encourage the students to think critically before they write their own narrative text which is ghost story or mystery based on the steps and scaffold given and learnt. The result on the questionnaire on Unit 6/Narrative Text will be discussed in Table 8 .

Table 8. Result on the Questionnaire on Unit 6/ Narrative Text

\begin{tabular}{|c|c|c|c|c|}
\hline $\begin{array}{l}\text { Topic/ } \\
\text { Genre }\end{array}$ & Skills & $\begin{array}{c}\text { Grade/ } \\
\text { Class }\end{array}$ & $\begin{array}{l}\text { Result on the } \\
\text { questionnaire }\end{array}$ & Reasons \\
\hline $\begin{array}{l}\text { - Unit } 6 \\
\text { - } \text { narrative } \\
\text { - } \text { The ma- } \\
\text { terial } \\
\text { covered } \\
\text { for the } \\
\text { try out } \\
\text { are the } \\
\text { listening } \\
\text { and } \\
\text { reading } \\
\text { skill and } \\
\text { the } \\
\text { gram- } \\
\text { mar. }\end{array}$ & $\begin{array}{l}\text { Listening } \\
\text { Speaking } \\
\text { Reading } \\
\text { Writing }\end{array}$ & $\begin{array}{l}\text { - } \mathrm{X}-1 \\
\text { class } \\
\text { - The } \\
\text { unit } \\
\text { was } \\
\text { tried } \\
\text { out to } \\
59 \\
\text { stu- } \\
\text { dents. }\end{array}$ & $\begin{array}{l}\text { - } 91.4 \%=\text { un- } \\
\text { derstood } \\
\text { learning ma- } \\
\text { terial given } \\
\text { on listening } \\
\text { in the form of } \\
\text { completion } \\
\text { and finding } \\
\text { main infor- } \\
\text { mation about } \\
\text { the text. } \\
\text { - } 91.5 \%=\text { liked } \\
\text { the listening } \\
\text { material } \\
\text { - When the stu- } \\
\text { dents were } \\
\text { asked to an- } \\
\text { swer ques- } \\
\text { tions based } \\
\text { on the text, } \\
\text { there was } \\
\text { only a slight } \\
\text { difference of } \\
\text { those who }\end{array}$ & $\begin{array}{l}\text { - The learning material } \\
\text { given on listening in the } \\
\text { form of completion and } \\
\text { finding main information } \\
\text { about the text were very } \\
\text { familiar to them and the } \\
\text { instructions were clear. } \\
\text { - They liked the listening } \\
\text { material given because it } \\
\text { was fun, relatively easy } \\
\text { and enhance the listening } \\
\text { ability to get details of } \\
\text { the text. } \\
\text { - In answering what type } \\
\text { of listening materials are } \\
\text { easily understood, they } \\
\text { suggested filling the gap } \\
\text { not only for stories but } \\
\text { also from songs. } \\
\text { - Those in favor of this ex- } \\
\text { ercise found it easy to get } \\
\text { the answers in the text } \\
\text { and helped them concen- } \\
\text { trating, understanding }\end{array}$ \\
\hline
\end{tabular}


Sukarni, Winarni, \& Nirmayanti,Improving Teacher's Professionalism 227

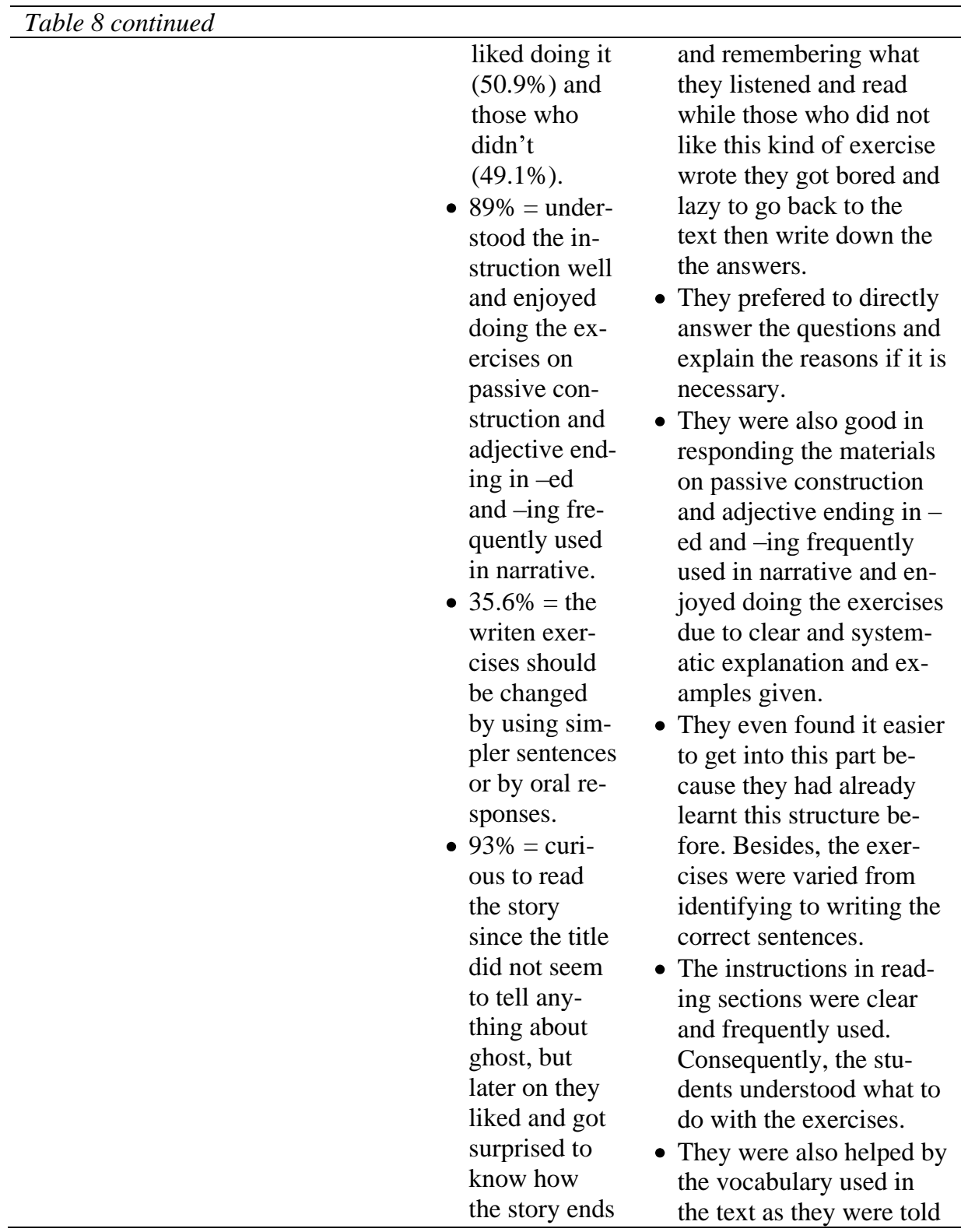




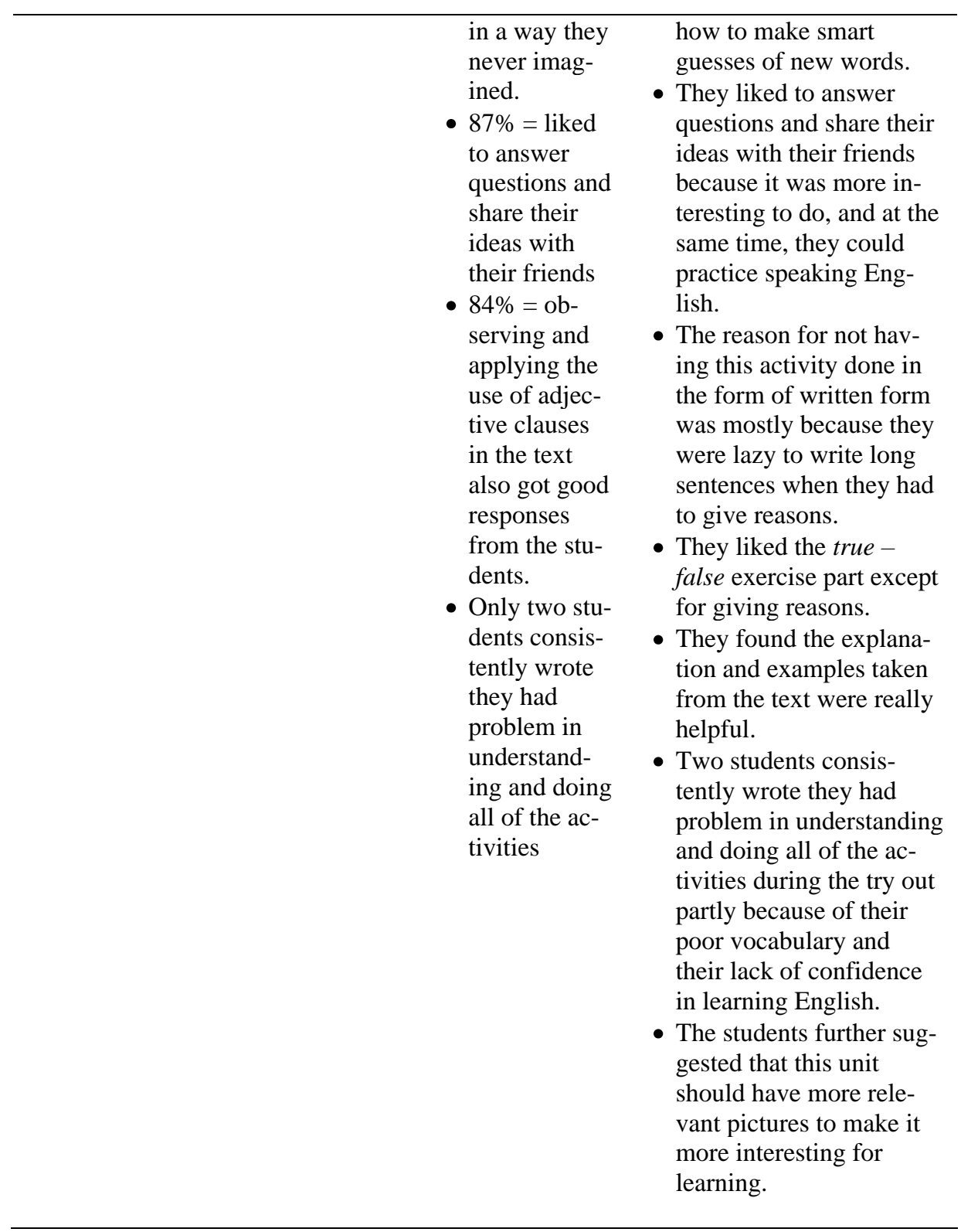


Sukarni, Winarni, \& Nirmayanti,Improving Teacher's Professionalism 229

$\begin{array}{ll}\text { Table } 8 \text { continued } & \text { The try out really shows } \\ & \text { material development as } \\ \text { an on going process } & \text { which needs to be con- } \\ \text { tinuously evaluated and } & \text { improved. }\end{array}$

\section{CONCLUSION AND SUGGESTIONS}

The essential part of material development process is aligning the material with students' needs and interests. The try out of the materials should be specifically and firmly designed and carried out since it reflects whether or not it has been well developed. In this research, the researchers developed several sub units and tried them out in July 2008. Furthermore, a try out on the worksheet consisting of adapted materials such as TOEFL, TOEIC, IELTS, IGCSE and compilation of grammar exercises was also conducted in the same period of time.

However, there is a problem in the diversities on mind set among teachers. As we all know, Indonesia has a varied situation in terms of geography, language, ethnic groups, religion, etc. That condition was not favorable to the improvement of teachers' professional skills through a change of mind set. However, results of the study above on material development showed that this effort could encourage the teachers' relationship with each other as a team. Through the collaboration in the cycles of CAR, the teachers were more confident of their capabilities in language learning and teaching.

The teachers involved in the CAR program were encouraged to enhance their level of competency, believe on their own capacity on English language competence, were willing to cooperate with issues such as the importance of IT facilities for the improvement of education, were eager to attend international seminars, publish the paper in a seminar proceedings (Sukarni et. al., 2007) and in an international journal. There was also problem in topic selection - junior teachers were more interested in more current issues, such as global warming, while senior teachers were more interested in the daily life issues. Such differences did not matter as long as the teachers were willing to learn new techniques and accommodate such differences in producing materials for the class. 
Another positive impact of professional development was teachers were exposed to wider exposure of teaching and learning, for example they became aware of many professional seminars and workshops on teaching and they were also motivated to present the results of their study at international seminars such as TEFLIN, ASIATEFL, etc. The teachers involved in this particular study were able to submit their paper at the seminars above.

It is suggested that all the activities that were carried out would be of benefit to the teachers if they were willing to cooperate with other teachers as a team. Another point was that the possibilities of other teachers involved in CAR at their own school would enhance their professional skills and in return would change their mind set.

\section{REFERENCES}

BSNP. 2006. Panduan Penyusunan Kurikulum tingkat Satuan Pendidikan Jenjang Pendidikan Dasar dan Menengah. Jakarta: BSNP.

Burns, A. 2003. Collaborative Action Research for English Language Teachers. Reprinted. Cambridge: Cambridge University Press.

Freeman, D. 1998. Doing Teacher-Research: From Inquiry to Understanding. Pacific Grove: Heinle \& Heinle Publishers.

Hutchinson, T. \& Waters, A. 2006. English for Specific Purposes. $22^{\text {nd }}$ printing. Cambridge: United Press.

Iragiliati, E. 1993. Discussing Professional Abstracts. In R.R.Day (ed) TESOL series: New Ways in Teaching Reading. Washington D.C.: TESOL.

Iragiliati, E. 2002. Let's Get Our River Back. In G. Jacobs \& A. Lie (Eds), English via Environmental Education (Pp. 65-69). Jakarta: Grasindo.

McDonough, Jo \& S. McDonough. 1997. Research Methods for English Language Teachers. London: Arnold.

Ministry of National Education. 2007. Pedoman Penjaminan Mutu Sekolah/Madrasah Bertaraf Internasional pada Jenjang Pendidikan Dasar dan Menengah. Jakarta: MONEF

Richards, J. C. 2001. Curriculum Development in Language Teaching. New York: Cambridge 
Sampoerna Foundation Teacher Institute. 2007. Characteristics and Indicators of National Plus Schools. Jakarta: Sampoerna Foundation.

Sukarni, E. I. 2005. Materials Related to Culture in a Multilingual Society. Paper presented at $53^{\text {rd }}$ TEFLIN International Conference. Yogyakarta: State University of Yogyakarta.

Sukarni, E. I., Suwarginingsih, M.N., \& Pudjiastuti. 2007. The Importance of a Change of Attitude related to Teachers' Professionalism: A Case Study at St. Albertus High School Malang. Paper presented at the $55^{\text {th }}$ TEFLIN International Conference (Proceedings), 28-33. Jakarta: Islamic State University Jakarta.

Sukarni, E. I. 2007. English for Medical Purpose, Indonesian for Medical Purpose, and its Pragmatics use. Malang: Bayumedia.

Sukarni, E. I., Ulfa, Farida., Octaviani, F., Isviola, M.A. 2008. THE SPOTLIGHT. High school textbooks X - XII grade science. XI - XII grade arts. Free download at'http://hibahbuku.wordpress.com

Van Lier, L. 1988. The Classroom and the Language Learner: Ethnography and second-language classroom research. New York: Longman.

Wallace, M. J. 1998. Action Research for Language Teachers. Cambridge: Cambridge University Press.

WWW.americanfolklore.ner

iwww.lestariheritage.ne

iwwW.culture.melayuonline.com 